NBER WORKING PAPER SERIES

SHIFTS IN THE NINETEENTH-CENTURY

PHILLIPS CURVE RELATIONSHIP

John A. James

Working Paper No. 1587

NATIONAL BUREAU OF ECONOMIC RESEARCH

1050 Massachusetts Avenue

Cambridge, MA 02138

March 1985

I am greatly indebted to the University of Virginia macroeconomics workshop, as well as Jonathan Eaton, Barry Eichengreen, Stanley Engerman, Ron Michener, Bart Taub, and Mark Thomas for comments and suggestions. The research reported here is part of the NBER's research program in Development of the American Economy. Any opinions expressed are those of the author and not those of the National Bureau of Economic Research. 


\section{Shifts in the Nineteenth-Century}

Philips Curve Relationship

\section{AB S TRACT}

This paper examines shifts in the output effects of unanticipated inflation in the nineteenth-century United States by estimating a Lucas-type aggregate supply function over the $1840-1900$ period. It is shown that, in contrast to the twentieth-century experience in which there has been a pronounced movement toward greater cyclical price rigidity, the nineteenthcentury output response to unanticipated price changes was roughly stable over the period. Such stability is also particularly interesting in view of the dramatic changes in communications and transportation technology, particularly the teleyraph and the railroad, which greatly facilitated information flows and thereby should have forced the price-surprise coefficient downward. Other factors which may have offset the influence of these improvements in information technology on the price-surprise coefficient include the reduced general price level variability due to the gold standard in the postbellum period and the possibility that the net effects of such improvements may in fact have been small because shocks were able to spread more rapidly as well. Finally, the perceived increase in cyclical price rigidity over the nineteenth century in the raw data is shown to have resulted not from a change in price-surprise coefficient. but rather from an increased degree of persistence or inertia in the economy.

John A. James Department of Economics University of Virginia Charlottesvilie, VA 22901 (804) $924-3525$ 
An important issue in macroeconomics has been whether the Philitips curve relationship has been changing over time toward greater price rigidity over the business cycle. It has often been argued that a given increase in the Tevei of unemployment is now associated with a smaller reduction in inflation than had been true in the past. In other words, the suggestion is that the output costs of lowering inflation has increased over time. Studies based essentialiy on twentieth-century U.S. data (e.g., Cagan, 1975; Sachs, 1980) in general confirm that the cycical rigidity of prices has been increasing. ${ }^{1}$ In his Phillips curve estimates Sachs $(p=83)$ finds, for example, a dramatic shift in the inflation-unemployment relationship between the pre-1929 and the post-World War II period - the estimated coefficients fali by more than 70 percent.

Greater historical perspective would be usefui in assessing long-term shifts in the degree of price rigidity over the business cycle. Aithough original studies of the Philitips curve (Philitips, 1958; Lipsey, 1960) were based on historical data, relatively little attention has been devoted to studying long-term changes since then. 2 This paper therefore will consider the American case between 1840 and 1900. The nineteenth-century experience should be especialiy interesting in terms of informational theories of the Phillips curve or aggregate supply (Phelps, 1970, pp. 6-7; Lucas, 1973). The theory suggests that if the economy were composed of a large number of scattered, competitive markets, or "islands", and information flows among them are costiy, suppliers of labor and goods would have difficulty in distinguishing relative price changes from general movements in the price level. The presence of imperfect information leads to a positive association of price and output changes in the short run as suppliers misinterpret general price level changes for relative price changes. In the nineteenth century 
when transportation and communication were significantiy more difficult and costly than today, this "isiand" characterization of markets should be particulariy appropriate. In view of some difficulties in estimating positive price-surprise terms in aggregate supply curves with contemporary data (Fair, 1979), the resuits for the nineteenth century in measuring the output response to inflationary surprises should be of some interest.

The basic historical evidence for the period $1835-1975$ is summarized in Tables I and II, and also in Tables IA and IIA. Tables I and II report the total change in wholesale prices from peak to trough of the business cycle to give an idea of the magnitude of decline, while Tables IA and IIA present the change in inflation rates resulting from the cycle. The change in inflation is measured as the difference between the inflation rate in the year prior to the peak of the cycle and the average rate of price change during the downturn (following Sachs). The change in the gap between actuai real output and potential output from peak to trough of the cycle (a widening of the GNP gap carries a minus sign) is used as a measure of the magnitude of the cycle and the cycles are grouped in terms of severity. ${ }^{3}$ Such a classification scheme allows contractions of a similar degree of severity to be compared directiy. Note first of a 11 however that three nineteenth-century periods, 1847-48, 1873-79, 1890-91, which had been previously classified as contractions on the basis of movements of NBER business cycle indicators, were in fact expansionary periods marked by a narrowing GNP gap. These, as a resuit, will be omitted in the period comparisons which follow.

The increase in cyclical rigidity in the post-World War II period is readily apparent. For mild contractions, downward price flexibility appears to have ended with the post-World War II period and the size of the reduction in the inflation rate declines significantly as well (the same is true for 
moderate contractions, but there is only one postwar observation here). Longer term trends are more difficult to discern from the tables however, so price and output gap changes over cyclical downturns with the trend line for the nineteenth and twentieth centuries respectively are plotted in Figures I and II. Comparing the nineteenth and twentieth century experience directiy is a rather dangerous enterprise because the figures are based on different data sources and output variability in the nineteenth century may be understated. 4 Nevertheless, increased price rigidity (fiatter siope) in the twentieth century is certainiy supported by the figures. Moreover, this trend remains even when the data are divided into shorter periods. Regressions of price change on output gap change with the observations grouped into three periods--pre-Civil War, Civil War to World War II, and post-Worid War II--show a progressively smalier coefficient in each period with the shifts being statistically significant in a likelihood ratio test. 5 This suggestion of $a$ very long term trend toward increased price rigidity from the raw data (from the antebeilum period on) however is primarily for a bit of (perhaps questionable) historical perspective. Problems of possibiy incomparabie data will be avoided by focusing on the nineteenth century.

Rather than such casual empiricism, as above, this paper will examine the issue of changing price rigidity, or in the context of an aggregate supply curve shifts in the output effects of unanticipated infiation, over the mid and late nineteenth century more formaliy. Distinguishing between anticipated and unanticipated inflation, I estimate an expectational aggregate supply curve over the period $1840-60,1870-1900$. This period is particularly interesting as well because it encompasses the diffusion of two of the most important improvements in communications and transportation, the telegraph and the railroad. It will be shown however that, notwithstanding the apparent 
trend toward greater cyclical price rigidity and the dramatic improvements in communications and transportation over the period, the output response to inflationary surprises was remarkabiy stable over the last sixty years of the nineteenth century. The sharp deciine in the siope of the twentieth-century Phillips curve therefore was not characteristic of the nineteenth century.

The estimation of the aggregate supply curve is described in Section I, while the resuits are anaiyzed in Section II. The conciusions appear in Section III, and the data are discussed in the Appendix.

II .

It is assumed that the aggregate suppiy function is the familiar expectational form with lagged adjustment, as in Lucas (1973).

$$
\left(y_{t}-y_{t}^{*}\right)=\alpha_{1}\left(y_{t-1}-y_{t-1}^{*}\right)+\alpha_{2}\left(p_{t}-E_{t-1} p_{t}\right)+\alpha_{0}+u_{t}
$$

where $y_{t}, y_{t}^{*}$, and $p_{t}$, are logarithms of real output, real potential output, and the price level respectively at time $t$. The variable $E_{t-1} p_{t}$ represents the public's expectation of the $\log$ of the price level in period $t$ as of the end of period t-1 based on information availabie at that point.

The gap between actual and potential output is a function of last period's gap and the difference between the actuai price level and the pubiic's expectation of it. Unanticipated price increases lead to increases in real output, a resuit consistent with a negatively sloped short-run Phillips curve, but a verticai long-run one. Gordon $(1980,1981,1982)$ has criticized such a specification for assuming complete rather than gradual 
price adjustment. Nevertheless, with annual data, as we have here, this does not seem to be an unreasonable characterization. 6

Potential output is taken to be a simple constant returns to scaie cobbDouglas function of exogenous factor inputs:

$$
\begin{aligned}
& y_{t}^{*}=\phi_{k t} k_{t}+\phi_{L t} \ell_{t}+\phi_{T t} t_{t}+A_{t} \\
& \text { with } \phi_{k t}+\phi_{L t}+\phi_{T t}=1
\end{aligned}
$$

where $k, \ell$, and $t$ are the logs of capital, labor, and land respectively; $\phi_{K t}$, $\phi_{L t}$, and $\phi_{T t}$ are the factor shares; and $A_{t}$ is the efficiency parameter at time $t$.

Substituting (2) into (1), we may rewrite the supply curve as:

$$
\begin{aligned}
y_{t} & =\phi_{K t} k_{t}+\phi_{L t} l_{t}+\phi_{T t} t_{t} \\
& +\alpha_{1}\left(y_{t-1}-\phi_{K t-1} k_{t-1}-\phi_{L t-1} l_{t}-\phi_{T t-1}{ }_{t-1}\right) \\
& +\alpha_{2}\left(p_{t}-E_{t-1} p_{t}\right)+\alpha_{3} t^{m_{m}}{ }_{t}+\alpha_{0}+u_{t}
\end{aligned}
$$

where changes in the efficiency parameter $A_{t}$ are captured by a time trend. Price expectations are taken to have been formed based on two lagged values of the price level. They are "economically rational" in the sense that given available information at the time the pubiic did not make systematic errors in forming expectations of future price levels (Feige and Pearce, 1976). Such a specification seems particuiariy appropriate for the nineteenth 
century when information on exogenous variabies must have been quite difficuit and costiy to obtain. 7

Equation (3) therefore was estimated concurrentiy with the price forecasting equation by instrumentai variabies. The instruments used included the exogenous and predetermined variables in the modei plus the logs of the money suppiy, government expenditures, and exports. ${ }^{8}$ The hypothesis of no first-order autocorreiation is not rejected using Godfrey's $\pi$ test (1976). The results for the equation estimated over the period 1841-1900 with a gap in the 1860's appear in the first line of Tabie III. The coefficient of the price surprise variable, $p_{t}-E_{t-1} p_{t}$, is positive and statistically significant, so that unanticipated increases in the price level elicits an increased supply of output, as in the traditional expectational Philiips curve. ${ }^{9}$ This result contrasts with the inability of Friedman and Schwartz (1982, p. 461) to identify a statistically significant Phillips curve relationship in the Inited States after 1867. With the exception of the interwar period, they find that the relation between price change and output change, if anything, was negative rather than positive. 10 The influence of the lagged output gap is significantiy positive and the time trend is as well, consistent with technical progress. The positive constant term might indicate some error in the measurement of potentiai output.

Deviations from full employment in the aggregate suppiy function of equation (1) are caused by aggregate demand shocks. Recent experience however has shown that suppiy-side shocks, where price and output movements are negatively rather than positively related, can also be important influences on the output gap and hence on the observed Phillips-curve tradeoff (Gordon, 1982; Froyen and Waud, 1984). Supply shocks in agricuiture (bad harvests, etc.) may have been particulariy important in nineteenth-century America, when 
agricuiture constituted a much larger proportion of total output than today. To allow for the influence of suppiy perturbations a supply-shock variable, $z_{t}$, measured here as the relative price of food products, 11 is included in the aggregate suppiy equation. The resuits of the estimation are presented in the second line of Table III. The coefficient of the supply-shock measure, $z_{t}$, is not significantiy different from zero, and the estimates of the other coefficients are essentialiy unchanged from their vaiues in line 1. Allowing for agricuitural supply shocks does not therefore affect our estimate of the tradeoff.

Gordon (1982, pp. 1090-1091) derives another formulation of the aggregate supply function in which the unanticipated component of nominai GNP change, $U \hat{Y}_{t}$, appears on the right-hand side of the equation rather than the price surprise.

$$
y_{t}-y_{t}^{*}=\frac{\alpha}{1+\alpha} U \hat{Y}_{t}+\lambda\left(y_{t-1}-y_{t-1}^{*}\right)+\frac{1}{1+\alpha} \varepsilon_{t}
$$

To separate the nominal GNP change into anticipated and unanticipated components, the nominal change is regressed on two lagged values each of changes in nominai GNP, the money stock, the rate of wholesaie price change, and the interest rate on government bonds, as well as the other right-hand side variables in the supply equation - the lagged output gap and time. The fitted values from the estimated equation are taken to represent expected income change, and the residuals, unanticipated changes in nominat income. 12 This proxy for $U \hat{Y}_{t}$ was then used in the estimation of equation (4). The results are reported in the third line of Table III. The estimated tradeoff coefficient, $\alpha$, is again significantiy positive and also of a similar magnitude (.6463) to those of the first two equations in Tabie III. The 
estimate of the Philitips curve parameter seems to be quite robust with respect to alternate specifications of the aggregate supply function. On average 39 percent $\left(\frac{\alpha}{(1+\alpha)}\right)$ of the unanticipated nominal change showed up as output change and 61 percent $\left(\frac{1}{1+\alpha}\right)$ as price change.

Did the Philiips curve relationship, that is, the output response to unanticipated inflation as given by $\alpha_{2}$, shift over the nineteenth century? The regression results from estimating equation (3) over two subperiods, divided by the Civil War decade, which appear in the first two lines of Table iv show an upward movement in the price-surprise coefficient $\alpha_{2} .13$ This is supported as we 11 by the set of regression results at the bottom of Table IV in which the sample size is increased by five year increments. The pattern is generaily one of a steadily increasing $\alpha_{2}$ over the postbellum period, indicating a shift toward a flatter Phillips curve (a smaller unanticipated price change associated with a given output change over the business cycle) which Sachs argues is characteristic of the twentieth century. However, a likelihood ratio test for a shift in $\alpha_{2}$ after the civil War decade produces a test statistic $\chi^{2}(1)=6.07$, significant at the 5 percent lever (3.84), but not at the 1 percent level $(6.63) .14$ Although there may have been a bit of trend toward larger output responses to a given unanticipated price change in the late nineteenth century, the shift does not appear neariy as pronounced as that in the following century. In contrast to the twentieth-century experience the output-unanticipated inflation tradeoff appears to have been roughly stable over the $1840-1900$ period. 
II.

The relative stability of the price-surprise coefficient $\alpha_{2}$ after 1840 is remarkable in view of the dramatic improvements in technology, particularly the telegraph and the railroad, which greatly facilitated information flows over the period. Commercial telegraphy beginning with Samuel F. B. Morse's famous cable in 1844 spread rapidly across the United States, so that within a decade more than 20,000 miles of telegraph line had been put in place. From its inception it was used primarily for business purposes, and its "market perfecting" impact in reducing information and transactions costs soon became apparent (Du Boff, 1983, pp. 255-258). The railroad network in the United States began to develop in the late antebellum period as well. From its beginnings in the $1830^{\prime} \mathrm{s}$, it tripled in size over the decade of the 1850's to a total of over 30,000 miles by 1860 . Growth in track mileage continued in the postbellum period, although at slower rates. The railroad was aiso an important force in promoting the integration of dispersed local markets (Chandier, 1977).

Some crude evidence of increased iocal market integration may be offered in the form of a significant decrease in the degree of geographical price dispersion over the early part of our period. Consider the variance of averaged first differences of logarithms of regional price indices as a measure of how closely prices move together (Hercowitz, 1981, p. 337).

$$
\begin{aligned}
& \Delta p_{t}=\frac{1}{N}\left(\begin{array}{c}
\Sigma \\
i
\end{array} p_{i t}\right) \\
& \sigma_{t}^{2}=\frac{1}{N} \sum_{i}\left(\Delta p_{i t}\right)^{2}-\left(\Delta p_{t}\right)^{2}
\end{aligned}
$$


where $p_{i t}$ is the logarithm of the price index of region $i$ at time $t$. Using the Coeiho and Shepherd (1974) indices of regional retail prices based on the Weeks Report (they exclude the South Atlantic and Western regions) as the price data, we see that the variance of regional price changes decreased by about 30 percent between the decade of the 1850 's and that of the 1870 's. 15 In the Lucas supply function $(1973, p .328) \alpha_{2}$ may be written as:

$$
\alpha_{2}=\left(\frac{\tau^{2}}{\sigma^{2}+\tau^{2}}\right) \gamma,
$$

where $\sigma^{2}$ represents the variance of the "prior" distribution of the log of the general price level for the traders, $\tau^{2}$ is the variance of the distribution of the deviation of prices in individual markets from the average, and $\gamma$ is the supply eiasticity with respect to price surprises. The term in parentheses then is the fraction of total individual price variance which is due to relative price variation.

Cukierman (1979) in turn generalized a price-surprise aggregate suppiy model to the case in which individuals may have access to price information from other markets rather than just observing the current price in her own market. In such a case the "Lucas type effect" becomes $\tau^{2} /\left(n \sigma^{2}+\tau^{2}\right)$, where $n$ is the number of other markets from which the individual has access to information. Information about general price movements is reinforced as the individual samples more and more markets, so the ratio $n \sigma^{2} / \tau^{2}$ is an increasing function of $n$. As $n$ increases, $\tau^{2} /\left(n \sigma^{2}+\tau^{2}\right)$ and hence $\alpha_{2}$ should decrease. As the number of other markets observed grows larger, the output effect grows weaker. Or, in other words, as price information becomes more widely diffused in the economy, the siope of the Philitips curve should become steeper. 
Moreover, improvements in communication and transportation should make local market prices less subject to pecuijariy local shocks. As a resuit, the degree of Tocal price variability $\tau^{2}$ should deciline, which aiso decreases $\alpha_{2}$. Both of these effects of improved communication and transportation technology, access to price information from other markets and reduced local price variability, therefore should work in the same direction, toward a fall in $\alpha_{2}{ }^{16}$ Suppliers of labor and goods would have been less likely to think that general price increases represented relative price changes in their favor and to increase output in response.

However, the price-surprise coefficient $\alpha_{2}$ (from Tabie IV) in fact remained roughily stable, or increased slightiy, rather than failing. What forces offset the effects of improvements in information technology? First of a11, the net effects of such changes are less clear because even though information is propagated more swiftly and efficientiy throughout the economy, shocks are spread more rapidiy as well. The relative position of individuals in locai markets may have been largely unchanged if at the same time information from other markets were available more rapidiy, shocks from the outside world impinged more quickly as well. For example, in the (pretelegraph) Panic of 1837 the wave of suspension of specie payments in local banks radiating outward from New York reached Boston in two days, Pittsburgh in five days, Detroit in seven days, and St. Louis in tweive days (Pred, 1973, pp. 250-252). In contrast, during the Panic of 1873 suspension in other financial centers followed that in New York aimost immediateiy (Sprague, 1910, p. 62).

In addition, the variance of the general price level, $\sigma^{2}$, which also affects $\alpha_{2}$, may have changed over the nineteenth century as well. The period before the Civil War was marked by a bimetaliic monetary standard, while from 
the Civil War until Resumption in 1879 the United States was on a fiat standard with floating exchange rates (the Greenback Era). In 1879 the monetary regime was switched to the gold standard. Even though the mean of the distribution of the log of the price level changed littie between the antebelium and postbelium periods, the degree of unpredictability decreased substantialiy - the variance of residuais from the price forecasting equation ( $\mathrm{log}$ of prices regressed on two lagged values) decilined from .278 for the 1841-60 period to .011 for 1871-1900, a shift that is significant at the 1 percent level. 17 The price level variance $\sigma^{2}$ should be inversely related to $\alpha_{2}$ from (5) - the higher the variance in the generai price level, the less favorable the tradeoff will be. 18 Thus, a decrease in price level variability or unpredictability resulting from the transition to convertibility (over the 1870 's) and the adoption of the goid standard (after 1879) would have pushed the $\alpha_{2}$ coefficient upward, contrary to the infiuences of improved transportation and communications.

The econometric evidence indicates that the price-surprise coefficient is roughiy stable over the 1840-1900 period, but at the same time the cyclical price and output gap change data (Tabies I and II) indicate a trend toward increased cyclical price rigidity (or a smailer output response to price changes) in the nineteenth as well as in the twentieth century. Such a trend was not due to a change in $\alpha_{2}$ but rather in the lagged output gap coefficient $\alpha_{1}$

In Table IV the shift in $\alpha_{1}$ is clear. The estimated coefficient which had been relatively smali in magnitude and not statisticaliy significantiy different from zero in the period before the Civil. War became much larger and statisticaliy significant in the period after the Civil War. The regressions at the bottom of Tabie IV confirm this change, showing increases in the 
magnitude of the estimated $\alpha_{1}$ coefficients and their associated $t$ statistics as the sample period is extended into the postbeilum era. The infiuence of the lagged output gap on the current gap appeared to be growing between 1840 and 1900. During a downturn, for example, the lagged effect of actual output faling below potential output would puil current output farther below potential than would have been predicted earlier, ceteris paribus. In other words, increased inertia in the economy or increased persistence effects of the deviation of output from its potential level was responsible for the apparent increase in cycilicai rigidity. 19

Explanations for this rise in the importance of lagged effects must remain primarily speculative here, but some possibilities may be identified. The first is based on the dramatic increase in the rates of savings and investment in the nineteenth-century United States. Over the middie third of the century the share of capital formation in gross national product. approximately doubled. 20 This sharp rise in the investment rate by itself could have played an important role in magnifying persistence effects over time periods if it takes some time to build new capital goods (Kydland and Prescott, 1982). Also, multiplier effects could amplify and draw out the influence of changes in the higher level of investment.

Another possible explanation is based on the increased specialization in the U.S. economy and within manufacturing in particular. With the growth of the manufacturing sector both capital and labor were applied to increasingiy specialized tasks. Over the nineteenth century, the use of skilied as opposed to unskilled labor increased dramatically (Wilitiamson and Lindert, 1980). While unskilled workers may have found it relatively easy to move from one industry to another, skilied workers were probabiy much iess mobile across industries at least in the short term. Much of the accumulated human capitai 
may have been relativeiy task specific and hence not readily transferabie into other industries. Similarly, machines came to be designed for increasingiy specialized purposes as well. Rosenberg (1976, pp. 9-31) describes the trend toward greater specialization in the machine tool industry, for example, and observes that "by 1880 the proliferation of new machine tools in American industry had begun to reach torrential proportions" (p. 24). If both 7 abor and capital had been becoming more "fixed" or industry-specific over time, the economy would have adjusted more slowly to demand shocks. The growth of the raiiroad expanded geographicai markets and facilitated interregional factor mobility, but at the same time increased human capital accumulation and specialization may have raised the barriers to intersectoral or interindustry mobility. As a result, the degree of inertia or persistence in the economy may aiso have increased.

\section{I I .}

Even though the direction of the long-term trend in the Philips curve reiationship has remained unchanged in the Innited States from at least 1840 onward--toward larger output changes in response to a given change in unanticipated inflation--there appears to be a distinct difference between the nineteenth and twentieth century experience. While the twentieth century shows a pronounced trend toward greater cycilical price rigidity, in the sense that a given rise in unemployment is associated with smailer and smailer reductions in inflation than in the past, in the period between 1840 and 1900 the change in the expectational Philips curve tradeoff was so smali that the relationship could be judged to have been a roughiy stable one. 21 This 
relatively stable relationship persists even after taking possibie changes in the nature of shocks to the economy into account. The inciusion of a supplyshock variable, relative agricuitural prices, does not significantly affect the estimated coefficients in the aggregate suppiy function. 22

This essential stability of the price-surprise coefficient is particulariy noteworthy in view of the rapid expansion of the telegraph and railroad after 1840 , which by improving information flows should have led to a steeper Phillips curve. Suppliers were less likely to be "fooled" into changing output in response to a change in the aggregate price level. Since $\alpha_{2}$ did not fall, other factors must have offset the influences of improved information flows. It is possible that the net effects of such improvements may have been smali because shocks as well as new information were able to spread more rapidiy. Another counteracting effect on $\alpha_{2}$ may have been the decreased variability of the general price level resulting from the move to the gold standard. Sufficient information on the functioning of nineteenthcentury labor markets is not available to assess whether there were substantial changes in the nature and extent of implicit contracting (in turn affecting $\alpha_{2}$ ), but it is a possibility in view of the dramatic changes in labor force composition over the period.

The trend toward greater cyclical price rigidity over the nineteenth century observed in the pattern of price and output gap changes over successive business cycles therefore were not so much the result of a shift in the output response to unanticipated inflation but rather of the increased influence of the lagged output gap on current output. The degree of inertia or persistence in the economy increased markediy over the period due perhaps to the sharp rise in the investment share of GNP or increased specialization 
in the economy which made adjustment to shocks and intersectoral mobility more difficuit.

The movement toward a substantially flatter Phillips curve relationship (larger $\alpha_{2}$ ) which appears characteristic of recent experience therefore does not seem to have been true for the eariier period. It in fact then is essentiaily a twentieth century phenomenon. Sachs (1980, pp. 87-88) emphasizes the influence of countercyclical macroeconomic policy and the spread of long-term wage contracts particulariy after world War II in reducing cyclical fiexibility. However, Spencer (1977) finds a significant decrease in downward cyclical fiexibility of individual prices from industries experiencing increases in concentration over the late nineteenth and eariy twentieth century. Perhaps the merger wave and attendent increases in industriai concentration should be accorded more attention in studies of increases in cycilical rigidity. 


\section{Data Appendix}

The annual real output series used here developed by Robert Galiman is unpublished but weil known. 23 Beginning in the mid $1830^{\prime}$ s, there is a gap over the decade of the 1860's. The years before 1859, which were census years in the original series, have been interpolated into calendar years. A potential difficulty with this series for measuring cycilcal fluctuations is that it omits changes in inventories. Evidence for the post-World War I period suggests that inventory fluctuations are very significant in business cycles (Abramovitz, 1950; Blinder and Holtz-Eakin, 1984). Neglecting inventory shifts then would understate the degree of output variability in the nineteenth century. Data are not available to measure these inventory shifts directly, while contradictory influences make it difficuit to puzzie out the relative degree of nineteenth-century inventory fluctuations. On the one hand, improvements in communications and transportation, particularly the railroad, have been widely argued to have reduced the levei of inventory holdings substantialiy, and thus the ratio of inventories to GNP (Du Boff, 1983). On the other hand, the shift in inventory composition away from farm to more manufacturing over the period may have increased totai variability.

Kuznets' solution to this problem involved simpiy projecting a regression line between annual inventory change on annual commodity output change for the interwar period back to the nineteenth century and calculating fitted values (1961, p. 601; also Kendrick, 1961, p. 277). This method, of course, does not capture any effects from structural change that may have been occurring. This measure of inventory change in turn was incorporated into Friedman and Schwartz's income estimates which begin in 1869 (1982, p. 100). However, estimating the aggregate supply curve (3) over the postbelium period with the 
Friedman and Schwartz real income figures produced results very similar to those from the regressions based on the Gallman series. For example, the Friedman and Schwartz price-surprise coefficient, $\alpha_{2}$, differed from the reported one by only +.045 , or less than 10 percent, with comparable $t$ statistics. The degree to which $\alpha_{2}$ is underestimated because the omission of inventory shifts understates output variability appears quite small, at least based on the Kuznets estimate of inventory changes. The Kuznets adjustment for inventory changes therefore would not appear to imply a different pattern of resuits or conciusions from those in the paper based on the Galiman series. Alternative series do not appear to be superior to the Galiman one in measuring output fluctuations. In particular, Romer (1984) has argued that the Frickey index of industrial production (1947) exaggerates the volatility of the pre-Worid War I economy. Such a measure may not be an accurate reflection of changes in aggregate output in any case in view of the substantial sectoral shift in the distribution of output that was taking piace over the period, with the share of agriculture in national income faliing from 26 to 15 percent, and that of manufacturing and mining was rising from 14 to 25 percent over the second half of the nineteenth century. Furthermore, the Galiman measure has the advantage of extending back into the antebelium period, which is especially interesting because of the spread of the telegraph and the railroad, while neither the Friedman and Schwartz income series nor the Frickey industrial production index go back before the Civil war.

There was considerable variation in the rate of growth of real output across subperiods between 1840 and 1900 (Abramovitz and David, 1973, p. 431), so a simple time trend is not a satisfactory measure of the growth of potential output over the period. The potential output series used in the 
regressions is built up from constructed annual series for capital, labor, and Tand.

Annual real capital stock figures were based on Davis and Gailman's Census year capitai-output ratios (1973, p. 457) and Galiman's annual gross capital formation series. Ising Census year capital stock figures as benchmarks, one may solve for average decadal depreciation rates and thus for an annual capitai stock series. Davis and Gallman (1973, pp. 463-466) show that capital stock figures calculated from investment flows are quite ciose to those from Census year benchmarks so that the capital stock and flow data, even though they come from different sources, are reasonabiy consistent and combining them, as is done here, is basically legitimate. 24 The Davis and Galiman capitai-output ratio estimates run from 1840 to 1900 , which 1 imits the time period for the regressions to those dates. In any case, the Galiman real output series extends oniy a few years earlier, into the mid 1830's.

Estimates of land inputs are caicuiated from Davis and Gallman's estimates of capital pius land-output ratios for Census years (p. 457) and then interpolated. Labor force figures are constructed from annual population estimates (U.S. Bureau of the Census, 1975, p. 8) and Lebergott's estimates of the labor force by Census years (Lebergott, 1964, p. 510). There were dramatic changes in the size of relative factor shares over this period, with the capital share rising from .27 to .37 between the $1834 / 36-1853 / 57$ and the 1888/92-1903/07 periods, while the labor share feil from .62 to .54, so clearly constant factor shares can not be assumed. Instead, time series for the factor shares-- $\phi_{L t}$, $\phi_{K t}$, and $\phi_{T t}$--are constructed by interpolating between midpoints of David's 15 year periods (1977, p. 189). Technical progress, the change in the efficiency parameter $A_{t}$, is captured by a time trend in the regressions. 25 
An alternative measure of potential output derived from projecting from a benchmark year of fuli employment along a trend rate of growth may aiso be constructed. In this case, estimates of $y_{t}^{*}$ are projected forward from the base year of 1834 using growth rates interpolated from David's period estimates of growth in real product (1977, p. 189). This estimate is used in calculating the output gap changes in Tabies I and II, and IA and IIA, because we don't know the values of $A_{t}$ in our first measure of potential output. The same pattern of regression results remain if the trend growth rate projected measure is used as $y_{t}^{*}$, with $\alpha_{2}$ increasing somewhat from .5977 to .8411 between the antebeilum and postbelium periods.

The price level is measured by the Warren-Pearson index of wholesale prices (1933, pp. 25-27). The underiying data for the series are primarily price quotations from New York markets. Changes in the degree of local price variability across regions therefore are not captured directiy in the price series. While changes in price variability across products may be refiected in the index, the influence of increasing integration of geographical markets is reflected oniy in so far as it affects local price variability in New York. However, the alternative price index spanning the period, the David and Solar cost-of-living index of retail prices $(1977, p .21$ ) is based on retail price quotations from only Massachusetts and Pennsyivania and thus its geographical coverage is oniy sightiy greater than the Warren-Pearson. The degree of variability in the wholesale price index is significantiy greater than in the navid and Solar consumer price index (David and Solar, 1977, pp. 20-21). For one thing, rent enters the index with a fairly large weight (17.7 percent for 1851-1880), and such prices are likely to be rather sticky in the short run (p. 55). Moreover, if the retail price markup adjusts oniy slowiy with a iag to changes in the wholesale market (pp. 52-55), the 
degree of variability in retail prices will be reduced for that reason as wel1. It would seem that the wholesale price index would be the one more relevant to suppliers in making output decisions, so we shall choose the Warren-Pearson index for this paper. 26 Ideal1y, we might prefer a GNP deflator series as the measure of $p_{t}$, but one is not available for this period.

As for the other instrumental variabies, government expenditures are taken as the sum of federal outiays (11.S. Bureau of the Census, 1975, p. 1114) and total state and local government expenditures (Davis and Legler, 1965), which constituted a substantial part of the total in the nineteenth century. Estimates of the money and specie stocks for the antebellum period are from Stevens (1971); for the postbellum period they are taken from Friedman and Schwartz (1970). Finaliy, exports are taken from (U.S. Bureau of the Census, 1975, pp. 864-865). 
Notes

1. Gordon (1980), who finds a stable relation over the period, is one exception to this generalization, but his estimates are not based on the expectational Philips curve specification. Wachter (1976) finds au contraire increasing cyciical responsiveness in wages in the postwar period, but Sachs (pp. 82-84) argues that his equations were misestimated.

2. Lipsey $(1960$, p. 27) also identifies a shift in the reiationship in the U.K. in the first part of the twentieth-century, around world War I - "The post-1922 experience was of less flexibility of wages in response to excess demand, whether positive or negative, than occurred in the pre-1914 period." 3. This classification scheme follows Sachs (1980, p. 81). However, the classifications of the cycles themselves may differ because his criterion is the change in the gap between actual and the trend levei of industrial production rather than between actual and potential real output. For exampie, the contraction of 1902-1904 which Sachs classes as moderate is identified here as mild; the downturn of 1918-19, labeled as strong by Sachs, is moderate here. The measure of potential output used here is described in the Data Appendix.

4. The Galiman GNP figures for the nineteenth century omit inventories. Since inventory fluctuations may have been significant over business cycies, output fluctuations will be understated (see the discussion in the Appendix). Also, to the extent that the derivation of the annuai series involved some interpolation some high frequency variability will be lost and annual output variability understated.

5. $\chi^{2}(2)=8.88$, which is significant at the 5 percent ievei. The estimated coefficients for the time periods are $2.37, .73$, and -2.31 respectively. A 
similar grouping for infiation rate changes as the dependent variable shows the same pattern of decreasing coefficients, but is not statisticaliy significant by the likelihood ratio test.

6. Moreover, in Gordon's gradual price adjustment equation estimated on quarteriy data for the 1892-1929 period, the closest we can come to the nineteenth century, the mean lag of past inflation variabies was less than a year and the coefficient of the lagged difference between actual and potential output was quite smait (.02). (Gordon, 1982, p. 1104)

7. In addition, adding lagged fiscal and monetary variables, such as government expenditures or the money supply, to the price forecasting equation makes very littie difference to the reported results. 8. Minor variations in the list of instruments, such as replacing the money stock by the specie stock or adding some international variables (see James, 1984, pp. 198-199) made no essential difference in the results.

9. Perhaps it should be reiterated here that because the dependent variable may understate the true level of output variability, the estimate of $\alpha_{2}$ here may be a bit too low. See note 4 .

10. Their specification however differs from the one used here. They use unanticipated price change as the dependent variabie and unanticipated money stock change and the output gap as independent variables. On the other hand, in this aggregate supply function and aiso in the relationship studied by Irving Fisher (1926) on eariy twentieth-century data the output gap is taken as the dependent variable.

11. Using relative agricuitural prices as a measure of suppiy shocks wouid be appropriate in a closed economy, but the nineteenth-century United States was a significant exporter of agricultural products. In that case, high foreign demand could lead to high relative farm prices, but it would be caused by a 
demand rather than supply shock. Therefore exports as a percentage of GNP can be included in our supply shock variable with a negative sign, $z z_{t}=z_{t}-$ $x_{t} / y_{t}$, to reduce foreign demand influences. The new variable should respond primarily to domestic suppiy shocks. However, when such a variabie was included in the aggregate supply curve, its coefficient also was not significantly different from zero, and the estimates of the other coefficients were not significantiy different from those reported in Table II. The conclusion reached in the text still appears to stand and is consistent with Temin's argument that the antebellum business cycle was driven by demand shocks (1974).

Alternative measures, the relative price of farm products or the rate of change of food prices, relative to the wholesale price index, (Warren and Pearson, 1933, pp. 25-27), made no significant difference to the reported resuits.

12. This procedure is described in more detait in Gordon (1982, pp. 1096$1097,1099)$.

13. In his estimates of the output-inflation tradeoff for the nineteenthcentury United States, Easton (1984, p. 526) finds a similar upward shift in the price-surprise coefficient.

14. A test for a shift in the pattern of price forecasting over the two subperiods cannot reject the nuil hypothesis of stability. The test statistic $F(2,53)=1.03$ was much less than the critical vaiue of 4.08 at the 5 percent leve1.

15. The decadai variance in the $1860^{\prime}$ 's however actualiy increased, presumabiy due to the Civil War.

16. It should perhaps be noted that the influence of the spread of the telegraph in lowering the cost of obtaining price information from other 
markets is not captured explicitiy in the specification of the price forecasting equation based on lagged general price level changes, and it is not clear how it shouid be modeled. One possibility is adding a time trend to the equation to represent improvements in the forecast over time due to increased information availability. In that case, the level, patterns of shift, and $t$ statistics of the price-surprise coefficients in equation (3) remain essentialiy the same as those reported in the text. Rather interestingiy the time trend coefficient in the forecasting equation is significantiy different from zero in the antebeilum period when telegraph and rail systems were expanding rapidly, but not in the postbellum period under the gold standard. The coefficient was also not significant when the equation was estimated over the whole period.

17. The test statistic $F(20,30)=25.49$ is much larger than the 1 percent significance leve1, 2.77. Comparing the entire antebelium period, 1801-60, with the 1871-1900 produces an even greater decline in variance, and omitting the years during and after the war of 1812 does not alter the resuits. Similarly, adding a time trend to the regression (in order to allow for a change in the mean over time) does not affect the resuits either. 18. The larger the shocks to the economy as evidenced in the degree of price level variability, the more incentive there is to distinguish between the nominal and real components of any nominal income change (Alberro, 1981, p. 248). Cukierman (1979) suggests that as $\sigma^{2}$ falls, individuals need to sample price information in fewer other markets, so changes in $n$ reinforce the effect of changes in $\sigma^{2}$ on $\alpha_{2}$ for a given technology. 19. This increased lag implies that the total effect of a price surprise on output would have risen significantiy over the nineteenth century even though the contemporaneous effect remained roughiy stable. The total multiplier of 
the price surprise, $\alpha_{2} /\left(1-\alpha_{1}\right)$, increased by 300 percent between the antebellum and postbellum periods.

20. In the 1839-1848 decade capital formation constituted an 11-12 percent share of GNP, while by 1879-1888 it had increased to 19 percent, and to 20-22 percent by 1889-1898. (Davis and Gailman, 1973, p. 439)

21. Data limitations unfortunately prevent the period from being extended eariier than 1840 , but the eariy part of the century is a very interesting period as well. Even without technological changes as dramatic as the telegraph and the railroad, there appear to have been significant improvements in information flows. Rothenberg, for example, in her study of Massachusetts farmers (1981, pp. 300-305) finds pronounced declines in the coefficient of variation over time for many crops, even eariy in the century when no important transport innovations had yet occurred. Pred (1973, pp. 20-77) finds a substantial decline in time lag of public information dissemination among cities before 1840 based on examinations of local newspapers. In addition if observations before 1840 had been available, we would have been able to observe the effects on the aggregate suppiy function of a dramatic change in information technology. Quite suggestively, David and Solar (1977, p. 30) find a marked dampening in the amplitude of short-term cycies in their change in labor-cost of living series. While many of the peak and trough rates of change were greater than +10 or -10 percent per annum before 1840 , the fluctuations in subsequent years were significantiy smalier.

22. Structurai change in the economy may affect the nature of the shocks. As the economy moved over time from an emphasis on agriculture to relatively more emphasis on manufacturing, the nature of shocks to the economy may have changed also - from suppiy shocks, where price and output changes are inversely related, associated with agriculture (bad harvests), to demand 
shocks, where price and output changes are positively related, more associated with manufacturing. If this had been the case and price and output changes were becoming more and more positively associated, then $\alpha_{2}$ would have been forced up over time due to structural change. We may reject this possibitity however because including a variable to capture the influence of supply shocks explicitly left the other coefficients essentialiy unaffected. 23. Obtained through private correspondence from Robert E. Gallman. 24. A bit more evidence and detail on this point is available in James (1984, p. 211$)$.

25. However, the changes in relative factor shares in fact suggest that technical change may have actualiy been more complex than the neutral specification postulated here. See David (1977). 26. However, the David and Solar consumer price index produces roughiy the same pattern of regression resuits. Since the variance of the index is smaller than that of the Warren-Pearson series the estimated $\alpha_{2}$ coefficients are larger. 
Table I

Price and Real Output Gap Changes During Business Cycles:

Mild Contractions, 1835-1975

Peak to Trough

$1836-38$
$1845-46$
$1847-48$
$1853-55$
$1873-79$
$1890-91$
$1895-97$
$1899-190$
$1902-04$
$1910-11$
$1923-24$
$1926-27$
$1948-49$
$1953-54$
$1957-58$
$1960-61$
$1969-70$
Change in Wholesale Prices

$-3.57$

0

$-9.31$

12.58

$-39.05$

0

$-4.32$

$+6.29$

$+1.2$

$-3.6$

$-2.7$

$-4.5$

$-5.1$

$+.2$

$+1.4$

$-\quad .4$

$+3.5$
Change in GAP

$-1.7$

$-.97$

$+.71$

$-4.44$

$+1.86$

$+1.01$

$-2.63$

$-.77$

$-3.32$

$-.92$

$-3.81$

$-3.73$

$-2.08$

$-4.52$

$-3.81$

$-1.29$

$-3.63$

Sources: The timing of nineteenth-century business cycles is taken from the NBER reference cycles (Hughes and Rosenberg, p. 485; Burns and Mitchel1, pp. 102-103). Nineteenth-century price movements are based on the Warren-Pearson wholesale price index (Warren and Pearson, pp. 25-27) and the twentieth century on the BLS wholesale price index (U.S. Historical Statistics, $p$. 200). Nineteenth-century real output movements are based on the Galiman series, while the twentieth-century figures are taken from Gordon (1981, pp. $x v-x v i$ i).

Notes: The change in prices is calculated as the percentage change in the log of the price index from peak to trough.

GAP is measured as the difference in the logarithms of actual real output and fuli empioyment output. The change in GAP therefore is the difference between its values at the peak and trough of the cycle, $\triangle G A P=G A P P^{-G A P}$. This procedure follows Sachs $(1980$, p. 81), aithough he measures deviations in industrial production rather than in real output. As a result, the two measures of cyclical severity are not strictly comparable. The cycles are grouped according to degrees of cyclical severity here as well, but the criteria are somewhat different: Mild contactions $-5 \leq \triangle G A P \times 100$; Moderate contractions, $-10 \leq \triangle \mathrm{GAP} \times 100 \leq-5$; Severe contractions, $\triangle G A P \times 100<-10$. 
Tabie IA

Inflation and Reai Output Gap Changes During Business Cycles: Mild Contractions, 1835-1975

\section{Price Changes}

\begin{tabular}{|c|c|c|c|c|}
\hline $\begin{array}{l}\text { Peak to } \\
\text { Trough } \\
\end{array}$ & $\begin{array}{l}\text { Year Before } \\
\text { Peak to Peak } \\
\text { (1) } \\
\end{array}$ & $\begin{array}{c}\text { Peak to Trough, } \\
\text { Annual Rate } \\
\text { (2) }\end{array}$ & $\begin{array}{c}\text { Change in } \\
\text { Price Inflation } \\
(2)-(1) \\
\end{array}$ & Change in GAP \\
\hline $\begin{array}{l}1836-38 \\
1845-46 \\
1847-48 \\
1853-55 \\
1873-79 \\
1890-91 \\
1895-97 \\
1899-1900\end{array}$ & $\begin{array}{r}13.10 \\
7.50 \\
8.10 \\
9.73 \\
-2.23 \\
1.23 \\
1.42 \\
8.11\end{array}$ & $\begin{array}{l}-1.79 \\
0 \\
-9.31 \\
6.29 \\
-6.51 \\
0 \\
-2.16 \\
6.29\end{array}$ & $\begin{array}{l}-14.89 \\
-7.50 \\
-17.41 \\
-3.44 \\
-4.28 \\
-1.23 \\
-3.58 \\
-1.82\end{array}$ & $\begin{array}{l}-1.7 \\
-.97 \\
+.17 \\
-4.44 \\
+1.86 \\
+1.01 \\
-2.63 \\
-.77\end{array}$ \\
\hline $\begin{array}{l}1902-04 \\
1910-11 \\
1923-24 \\
1926-27 \\
1948-49 \\
1953-54 \\
1957-58 \\
1960-61 \\
1969-70\end{array}$ & $\begin{array}{r}6.4 \\
4.2 \\
3.9 \\
-3.2 \\
7.9 \\
-1.3 \\
2.8 \\
.1 \\
3.8\end{array}$ & $\begin{array}{r}.6 \\
-8.3 \\
-2.7 \\
-4.5 \\
-5.1 \\
.2 \\
1.4 \\
-.4 \\
3.5\end{array}$ & $\begin{array}{r}-5.8 \\
-12.5 \\
-\quad 6.6 \\
-1.3 \\
-13.0 \\
1.5 \\
-1.4 \\
-\quad .6 \\
-\quad .3\end{array}$ & $\begin{array}{l}-3.32 \\
-. .92 \\
-3.81 \\
-3.73 \\
-2.08 \\
-4.52 \\
-3.81 \\
-1.29 \\
-3.63\end{array}$ \\
\hline
\end{tabular}


Table II

Price and Real Output Gap Changes During Business Cycles:

Moderate and Severe Contractions, 1835-1975

Peak to Trough

Change in Wholesale Prices

Change in GAP

\section{Moderate Contractions}

$1839-43$

$1856-58$

$1882-85$

$1887-88$

$1913-14$

$1918-19$

$1937-38$

$1973-75$
$-40.10$

$-12.14$

$-23.95$

$+1.17$

$-2.2$

$+5.72$

$-8.90$

$+26.2$
$-6.2$

$-5.09$

$-8.82$

$-5.41$

- 6.69

$-5.72$

$-6.94$

- 8.97

Severe Contractions

$$
\begin{aligned}
& 1893-94 \\
& 1907-08 \\
& 1920-21 \\
& 1929-33
\end{aligned}
$$

$$
\begin{aligned}
& -10.82 \\
& -3.6 \\
& -46.0 \\
& -30.71
\end{aligned}
$$$$
-11.09
$$

$-12.07$

$-11.29$

$-45.68$ 
Table IIA

Inflation and Real Output Gap Changes During Business Cycles:
Moderate and Severe Contractions, 1835-1975

\section{Price Changes}

\begin{tabular}{lcc} 
Year Before & Peak to Trough, \\
Peak to & Peak to Peak & Annual Rate \\
Trough & (1) & (2) \\
\hline
\end{tabular}

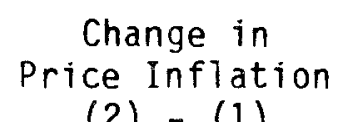

(2) $-(1)$

Change in GAP

Moderate Contractions

$1839-43$

1856-58

1882-85

1887-88

1913-14

1918-19

1937-38

1973-75

1893-94

1907-08

1920-21

1929-33

\section{Severe Contractions}

1.80
-4.64
4.74
3.59

1.1

10.9

6.8

12.3
$-10.03$

$-6.07$

$-7.98$

$+1.17$

$-2.2$

$-5.5$

$-8.9$

13.1

$$
\begin{array}{r}
-11.83 \\
-1.42 \\
-12.72 \\
-2.42 \\
-3.3 \\
-16.4 \\
-15.7 \\
.8
\end{array}
$$

$-6.2$

$-5.09$

- 8.82

$-5.41$

$-6.69$

$-5.72$

-6.94
-6.97

$-8.97$

$\begin{array}{rrl}1893-94 & 2.60 & -10.82 \\ 1907-08 & 4.8 & -3.6 \\ 1920-21 & 10.8 & -46.0 \\ 1929-33 & -1.7 & -7.68\end{array}$

$-13.42$

$-11.09$

$-8.4$

$-12.07$

$-56.8$

$-11.29$

-5.98
-58

$-45.68$ 
Tabie III

Estimates of the Aggregate Supply Function, 1841-1858, 1871-1900

( $t$ statistics in parentheses)

$$
\begin{aligned}
& y_{t}=y_{t}^{*}+\underset{(4.69)}{.5236}\left(y_{t-1}-y_{t-1}^{\star}\right)+\underset{(4.46)}{.5495}\left(p_{t}-E_{t-1} p_{t}\right)+\underset{(3.48)}{.00168} \text { time }_{t} \\
& -.4881 \\
& (-4.16) \\
& y_{t}=y_{t}^{*}+\underset{(4.60)}{.5214}\left(y_{t-1}-y_{t-1}^{*}\right)+\underset{(3.75)}{.5703}\left(p_{t}-E_{t-1} p_{t}\right)+\underset{(3.44)}{.00167} \text { time }_{t} \\
& +.0768 z_{t}-i .4893 \\
& y_{t}=y_{t}^{\star}+\frac{.6463}{(1+.6463)} u \hat{Y}_{t}+.6334\left(y_{t-1}-y_{t-1}^{\star}\right)+.0012 \text { time }_{t}-.3675 \\
& (3.80) \\
& \text { (7. 78) }
\end{aligned}
$$


Table IV

Aggregate Supply Function Estimated Over Subperiods ( $t$ statistics in parentheses)

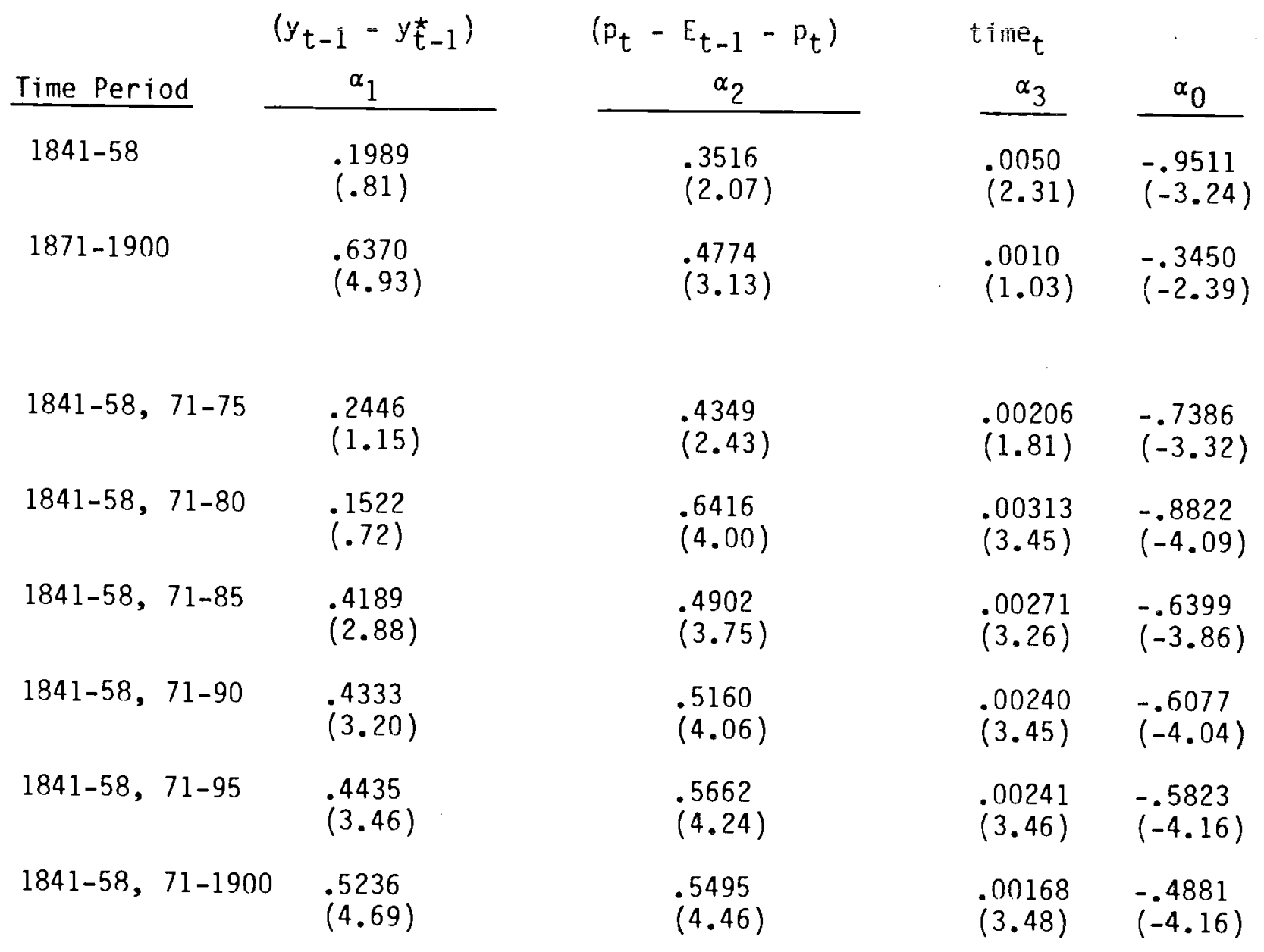


$\Delta p^{2}$

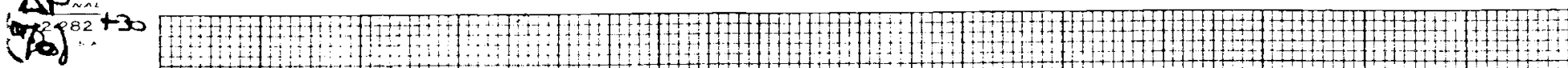
tat (1)

FIQURE I

+20 PRICE LEVEL AND OUTPOT GAP CHANGES

OWER CYCLICAL DOWNTURNS $1835-1900$

$+10$

0

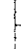
$\vdots: \vdots$

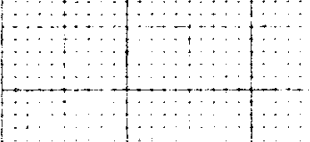

10
-10

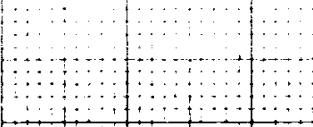

$-30$

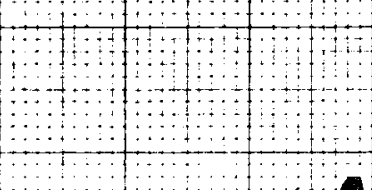

$-20$

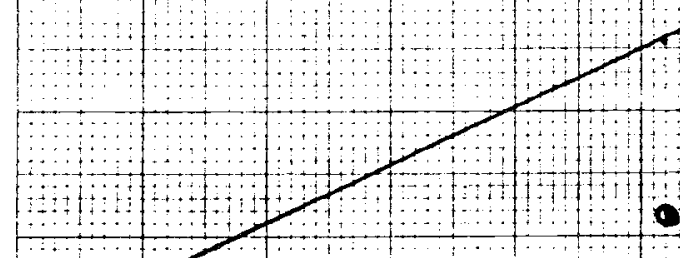

$6+111+4+4+4$

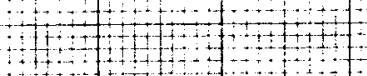

$-40$
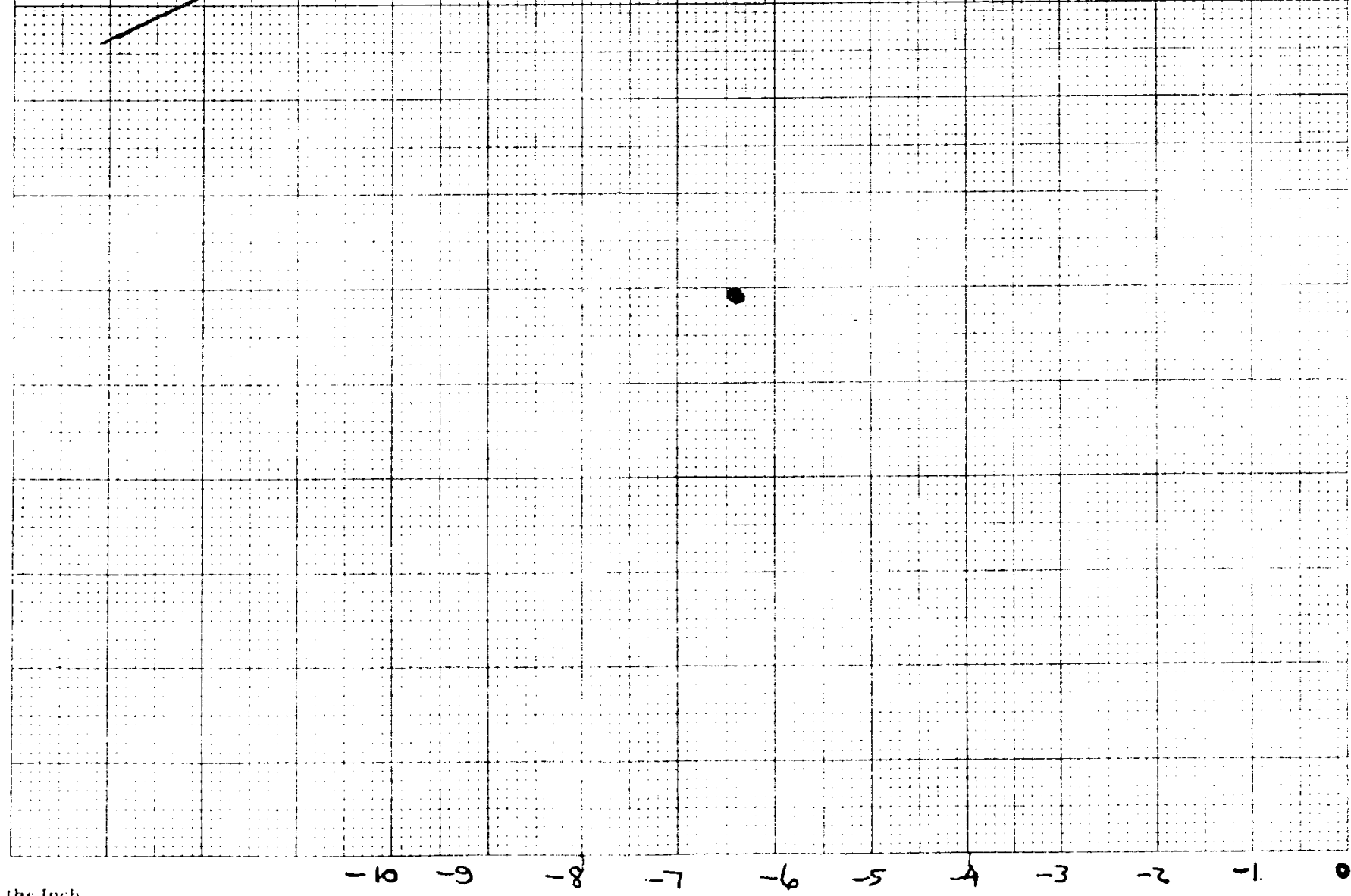


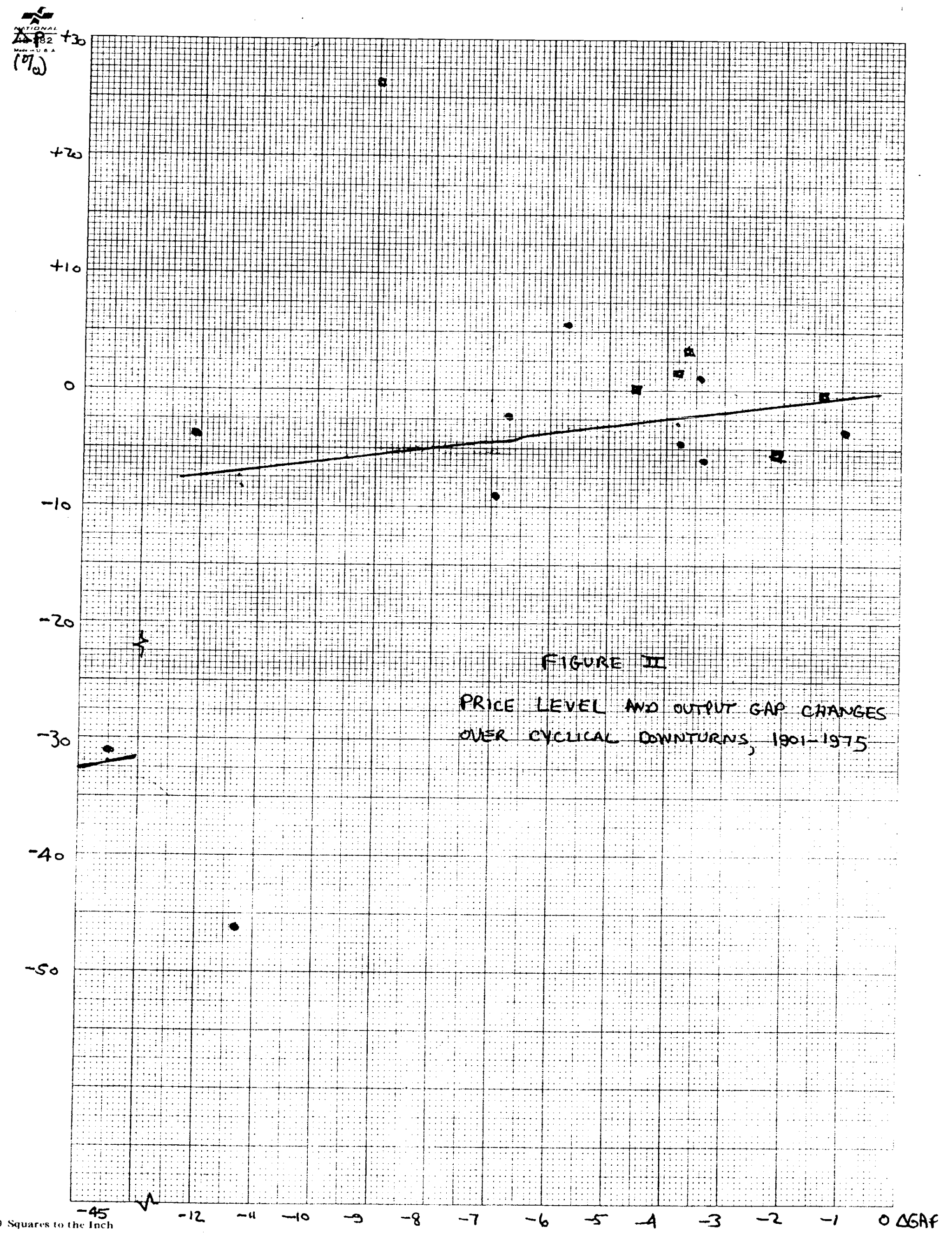


References

Abramovitz, Moses (1950), Inventories and Business Cycles. New York: National Bureau of Economic Research.

Abramovitz, Moses, and David, Paul A. (1973), "Reinterpreting Economic Growth:

Parables and Realities." American Economic Review Papers and Proceedings $63,428-439$.

Aiberro, Jose (1981), "The Lucas Hypothesis on the Philitips Curve." Journal of Monetary Economics $7,239-250$.

Blinder, Alan, and Holtz-Eakin, Douglas (1984), "Inventory Fluctuations in the United States since 1929," NRER Working Paper No. 1371.

Burns, Arthur F., and Mitcheil, Wesiey C. (1946), Measuring Business Cycles.

New York: Nationai Bureau of Economic Research.

Cagan, Philip (1975), "Changes in the Recession Behavior of Wholesale Prices

in the 1920's and Post-Worid War II." Explorations in Economic Research

$2,54-104$.

Chandier, Alfred D. (1977), The Visible Hand. Cambridge, Mass.: Harvard University Press.

Coeiho, Philip, and Shepherd, James (1974), "Differences in Regional Prices:

The United States, 1851-1880." Journal of Economic History 34, 551-591.

Cukierman, Alex (1979), "Rational Expectations and the Role of Monetary

Poilicy," Journal of Monetary Economics 5, 213-229.

David, Paul A. (1977), "Invention and Accumulation in America's Economic Growth: A Nineteenth Century Parabie." In Kari Brunner and Alian Meltzer (Eds.), International Organization, National Policies and Economic

Development. Amsterdam: North Holland. Pp. 179-228. 
David, Paul A., and Solar, Peter (1977), "A Bicentenary Contribution to the History of the Cost of Living in America." In Paul Uselding (Ed.), Research in Economic History, Volume 2, Greenwich, Ct.: JAI Press. Pp. 1-80.

Davis, Lance E., and Gallman, Robert E. (1973), "The Share of Savings and Investment in Gross National Product During the 19th Century in the U.S.A." In F. C. Lane (Ed.), Fourth International Conference of Economic History. Paris: Mouton, pp. 437-466.

Davis, Lance E., and Gailiman, Robert E. (1978), "Capitai Formation in the United States during the Nineteenth Century." In Cambridge Economic History of Europe. New York: Cambridge University Press. Volume VII, Part 2, pp. 1-69.

Davis, Lance E., and Legier, John B. (1966), "The Government in the American Economy, 1815-1902: A Quantitative Study." Journal of Eronnmic History $26,514-552$.

Du Boff, Richard (1983), "The Teiegraph and the Structure of Markets in the United States, 1845-1890." In Paul Useiding (Ed.), Research in Economic History, Volume 8. Greenwich, Ct.: JAI Press, pp. 253-277. Easton, Stephen (1984), "Real Dutput and the Gold Standard Years, 18301913." In Michael Bordo and Anna Schwartz (Eds.), A Retrospective on the Classical Gold Standard, 1821-1931. Chicago: University of Chicago Press, pp. 513-538.

Fair, Ray C. (1979), "An Anaiysis of the Accuracy of Four Macroeconomic Models." Journal of Political Economy 87, 701-718.

Feige, Edgar, and Pearce, Douglas (1976), "Economicaliy Rational Expectations: Are Innovations in the Rate of Inflation Independent of Innovations in 
Measures of Monetary and Fiscal Policy?" Journal of Political Economy $84,499-522$.

Fisher, Irving (1926), "A Statistical Relation between Unemployment and Price Changes." International Labour Review 6, 785-792.

Frickey, Edwin (1947), Production in the United States, 1860-1914. Cambridge, Mass.: Harvard University Press.

Friedman, Milton, and Schwartz, Anna J. (1970), Monetary Statistics of the

United States. New York: Nationai Bureau of Economic Research.

Friedman, Milton, and Schwartz, Amna J. (1982), Monetary Trends in the United

States and the United Kingdom. Chicago: University of Chicago Press.

Froyen, Richard T., and Waud, Roger N. (1984), "The Changing Relationship

between Aggregate Price and Output: The British Experience." Economica

$51,53-67$.

Galiman, Robert E. (1966), "Gross National Product in the United States, 18341909." In Output, Employment, and Productivity in the United States

After 1800. Volume 30, Studies in Income and Wealth. New York: National Bureau of Economic Research. Pp. 3-75.

Godfrey, L. G. (1976), "Testing for Serial Correlation in Dynamic Simultaneous Models." Econometrica 44, 1077-1084.

Gordon, Robert J. (1980), "A Consistent Characterization of a Near Century of Price Behavior." American Economic Review Papers and Proceedings 70, 243-249.

Gordon, Robert J. (1981a), Macroeconomics. Boston: Little, Brown. Gordon, Robert J. (1981b), "Output Fluctuations and Gradual Price

Adjustment." Journal of Economic Literature 19, 493-530. Gordon, Robert J. (1982), "Price Inertia and Policy Ineffectiveness in the United States, 1890-1980." Journal of Poiltical Economy 90, 1087-1117. 
Hercowitz, Zvi (1981), "Money and the Dispersion of Relative Prices." Journal of Political Economy $89,328-356$.

James, John A. (1984), "Public Debt Management Policy and Nineteenth-Century American Economic Growth." Explorations in Economic History 21, 192-217. Kendrick, John W. (1961), Productivity Trends in the United States.

Princeton: Princeton University Press.

Kuznets, Simon (1961), Capital in the American Economy. Princeton: Princeton University Press.

Kydiand, Finn, and Prescott, Edward (19982), "Time to Builid and Āggregate Fluctuations," Econometrica 50, 1345-1370.

Lebergott, Stanley (1964), Manpower in Economic Growth. New York: McGrawHi 11 .

Lipsey, Richard (1960), "The Relation between Unemployment and the Rate of Change of Money Wage Rates in the United Kingdom, 1862-1957: A Further Anatysis." Economica 27, 1-31.

Lucas, Robert E. (1973), "Some International Evidence on Output-Inflation Trade-offs." American Economic Review 63, 326-334. Lucas, Robert E. (1975), "An Equilibrium Model of the Business Cycle." Journal of Political Economy 83, 1113-1144.

Phelps, Edmund, ed. (1970), Microeconomic Foundations of Employment and Inflation Theory. New York: W. W. Norton.

Phillips, A. W. (1958), "The Relation between Unemployment and the Rate of Change of Money Wage Rates in the United Kingdom, 1861-1957." Economica $25,283-299$.

Pred, Altan R. (1973), Urban Growth and the Circulation of Information: The United States System of Cities, 1790-1840. Cambridge, Mass.: Harvard University Press. 
Romer, Christina (1984), "Is the Stabilization of the Postwar Economy A

Figment of the Data?", unpublished manuscript.

Rosenberg, Nathan (1976), Perspectives on Technology. Cambridge: Cambridge University Press.

Rosenberg, Nathan, and Hughes, Jonathan R. T. (1963), "The United States

Business Cycle before 1860: Some Problems of Interpretation." Economic

History Review 15, 476-493.

Rothenberg, Winifred (1981), "The Market and Massachusetts Farmers, 1750-

1855." Journal of Economic History 41, 283-314.

Sachs, Jeffrey (1980), "The Changing Cyclical Behavior of Wages and Prices:

1890-1976." American Economic Review 70, 78-90.

Spencer, Austin (1977), "Relative Downward Industrial Price Flexibility, 1870-

1921." Explorations in Economic History 14, 1-19.

Sprague, 0. M. W. (1910), History of Crises under the National Banking

System. Washington: Government Printing office.

Stevens, Edward J. (1971), "Composition of the Money Stock Prior to the Civil

War." Journal of Money, Credit, and Banking 3, 84-101.

Temin, Peter (1974), "The Anglo-American Business Cycle, 1820-1860." Economic History Review 27, 207-221.

U. S. Bureau of the Census (1975), Historical Statistics of the United

States. Washington, D.C.: Government Printing Office.

Wachter, Michael (1976), "The Changing Cyclical Responsiveness of Wage

Inflation." Brookings Papers on Economic Activity 1, 115-168.

Warren, George F., and Pearson, Frank A. (1933), Prices. New York: John Wiley.

Williamson, Jeffrey G., and Lindert, Peter (1980), American Inequality. New

York: Academic Press. 